\title{
Modeling Nutrient Fluxes and Plasma Ketone Bodies in Periparturient Cows
}

\author{
J. Guo, R. R. Peters, and R. A. Kohn ${ }^{1}$ \\ Department of Animal and Avian Sciences, University of Maryland, College Park 20742
}

\begin{abstract}
A mechanistic model was developed to study the interrelationship between glucose and lipid metabolism in periparturient cows. The driving variables were dry matter intake, feed composition, calf birth weight, milk production, and milk components. The response variables were body fat content and concentrations of plasma glucose, glycerol, nonesterified fatty acids (NEFA), and total ketone bodies (KB). Fetal growth and milk synthesis were assigned the highest priority for glucose demand in the model. The rate of fat mobilization was expressed as a function of glucose deficiency. The model assumed first-order kinetics for utilization of NEFA and KB. Model prediction errors were $19,43,48$, and $36 \%$ of mean predictions for glucose, glycerol, NEFA, and KB, respectively. A linear bias was observed in KB and glycerol predictions. The model may be useful for understanding and explaining ketosis development.
\end{abstract}

Key words: mechanistic model, glucose metabolism, lipid metabolism, periparturient cow

\section{INTRODUCTION}

Ketosis causes economic losses in dairy herds directly by decreasing milk production and indirectly by increasing the risk for other periparturient diseases. Ketosis development results from the complicated interaction between glucose and lipid metabolism. Glucose deficiency may occur in periparturient cows because the demand for glucose is increased greatly by milk synthesis while DMI lags behind the requirements for milk production. Krebs (1966) proposed long ago that glucose deficiency depletes oxaloacetate, and that ketosis development results from the deficiency of oxaloacetate needed for the catabolism of acetylCoA. However, experimental results often cannot be explained by Krebs' theory (Drackley et al., 2001) indicating that other interactions between glucose

Received December 18, 2007.

Accepted July 6, 2008.

${ }^{1}$ Corresponding author: rkohn@umd.edu and lipid metabolism are also involved in ketogenesis. Glycerol from fat mobilization may be an important gluconeogenic precursor as the cow adapts to lactation (Drackley et al., 2001). Therefore, ketosis development in periparturient cows may result from excessive fat mobilization for glycerol to compensate for glucose deficiency.

A metabolic model of energy metabolism has been developed (Baldwin, 1995) and evaluated for the periparturient period (McNamara and Baldwin, 2000), but this model did not deal with the issue of ketone body accumulation. The objectives of the current study were 1) to quantitatively evaluate the relationship between nutrient fluxes and blood ketone bodies using quantities of blood metabolites and literature-derived rates of metabolite synthesis and utilization, and 2) to develop a mathematical model that may predict plasma ketone body concentrations from easily obtained data such as milk production and dry matter intake. Such a model could be used to demonstrate the theory behind ketosis, and might be used to predict the risk of its occurrence.

\section{MATERIALS AND METHODS}

\section{Data}

The developmental data set used to parameterize the model was described previously (Guo et al., 2007). Twenty-eight multiparous Holstein cows were fed a nonlactating-cow diet prepartum and a lactation diet postpartum. Half of the cows were used as the control group. A transition diet was fed to the other half (the treatment group) for $17 \mathrm{~d}$ before calving date until 14 $\mathrm{d}$ postcalving. The nonlactating-cow diet contained $1.54 \mathrm{Mcal}$ of $\mathrm{NE}_{\mathrm{L}} / \mathrm{kg}, 10.9 \% \mathrm{CP}$, and $53.1 \% \mathrm{NDF}$, and the lactation diet $1.77 \mathrm{Mcal}$ of $\mathrm{NE}_{\mathrm{L}} / \mathrm{kg}, 16.8 \% \mathrm{CP}$, and $29.9 \% \mathrm{NDF}$. The transition diet $\left(1.71 \mathrm{Mcal}\right.$ of $\mathrm{NE}_{\mathrm{L}} / \mathrm{kg}$, $16.8 \% \mathrm{CP}, 35.2 \% \mathrm{NDF}$ ) had a lower energy density compared with the lactation diet.

\section{The Model}

A representation of the model is shown in Figure 1 and Tables 1 and 2. The driving variables were DMI, feed composition, calf birth weight, milk production, 
Table 1. Principal symbols used in the model

\begin{tabular}{|c|c|c|}
\hline Symbol & Unit & Definition \\
\hline $\mathrm{t}$ & $\mathrm{d}$ & Day relative to calving \\
\hline Adi & $\%$ & Rumen adaptation index \\
\hline $\mathrm{P}_{\text {(propionate) }}$ & $\mathrm{mol} / \mathrm{d}$ & Production rate of propionate from fermentation \\
\hline $\mathrm{P}_{\text {(butyrate) }}$ & $\mathrm{mol} / \mathrm{d}$ & Production rate of butyrate from fermentation \\
\hline $\mathrm{P}_{\text {(glucose, protein) }}$ & $\mathrm{mol} / \mathrm{d}$ & Production rate of glucose from MP \\
\hline Fetus (glucose) & $\mathrm{mol} / \mathrm{d}$ & Glucose required for fetal growth per day \\
\hline Milk (glucose) & $\mathrm{mol} / \mathrm{d}$ & Glucose required for milk synthesis per day \\
\hline Peri $_{\text {(glucose) }}$ & $\mathrm{mol} / \mathrm{d}$ & Glucose utilized by peripheral tissues per day \\
\hline$[\text { Glucose }]_{p}$ & $\mathrm{~m} M$ & Glucose concentration in plasma \\
\hline$[\text { Glycerol }]_{\mathrm{p}}$ & $\mathrm{m} M$ & Glycerol concentration in plasma \\
\hline$[\mathrm{NEFA}]_{\mathrm{p}}$ & $\mathrm{m} M$ & NEFA concentration in plasma \\
\hline$[\mathrm{KB}]_{\mathrm{p}}$ & $\mathrm{m} M$ & Total ketone body $(\mathrm{KB})$ concentration in plasma \\
\hline Fat & $\mathrm{kg}$ & Body fat content \\
\hline $\mathrm{U}_{\text {(peri, glucose) }}$ & $\mathrm{mol} / \mathrm{d}$ per $\mathrm{kg}$ of $\mathrm{BW}^{0.75}$ & Utilization rate of glucose by peripheral tissues \\
\hline $\mathrm{P}_{\text {(fat, adipose) }}$ & $\mathrm{kg} / \mathrm{d}$ per $\mathrm{kg}$ of body fat & Mobilization rate of fat from adipose tissues \\
\hline $\mathrm{P}_{\text {(glucose, glycerol) }}$ & $\mathrm{mmol} \times \mathrm{mmol}^{-1}$ & Production rate of glucose from glycerol \\
\hline $\mathrm{T}_{\text {(fat, adipose) }}$ & $\mathrm{kg} / \mathrm{d}$ per $\mathrm{kg}$ of body fat & Turnover rate of adipose tissues before $7 \mathrm{~d}$ prepartum \\
\hline $\mathrm{U}_{(\mathrm{NEFA})}$ & $\mathrm{mmol} / \mathrm{d}$ per $\mathrm{mmol}$ & Utilization rate of NEFA \\
\hline $\mathrm{U}_{(\mathrm{KB})}$ & $\mathrm{mmol} / \mathrm{d}$ per $\mathrm{mmol}$ & Utilization rate of $\mathrm{KB}$ \\
\hline
\end{tabular}

and milk components. The response variables were body fat content and the concentrations of plasma glucose, glycerol, NEFA, and KB (sum of BHBA, acetoacetate, and acetone).

Response Variables. The plasma glucose concentrations depended on the rate of glucose synthesis from glycerol, the rates of gluconeogenesis from propionate and amino acids, the rate of glucose utilization by peripheral tissues, and the rates of glucose utilization for fetal growth and milk synthesis. The model assumed that glycerol released from fat mobilization was com- pletely utilized for glucose synthesis. Glucose utilized by peripheral tissues was expressed as a function of glucose concentration in plasma and metabolic body weight (Table 2).

The glycerol concentrations depended on fat mobilization and the rate of gluconeogenesis from glycerol. Glycerol used for lipogenesis in adipose tissues was not accounted for in the kinetics of glycerol concentrations, but was considered glucose consumption by peripheral tissues in the model. Total body fat $(\mathrm{kg})$ depended on the rate of adipose mobilization $(\mathrm{kg} / \mathrm{d}$ per $\mathrm{kg}$ of body

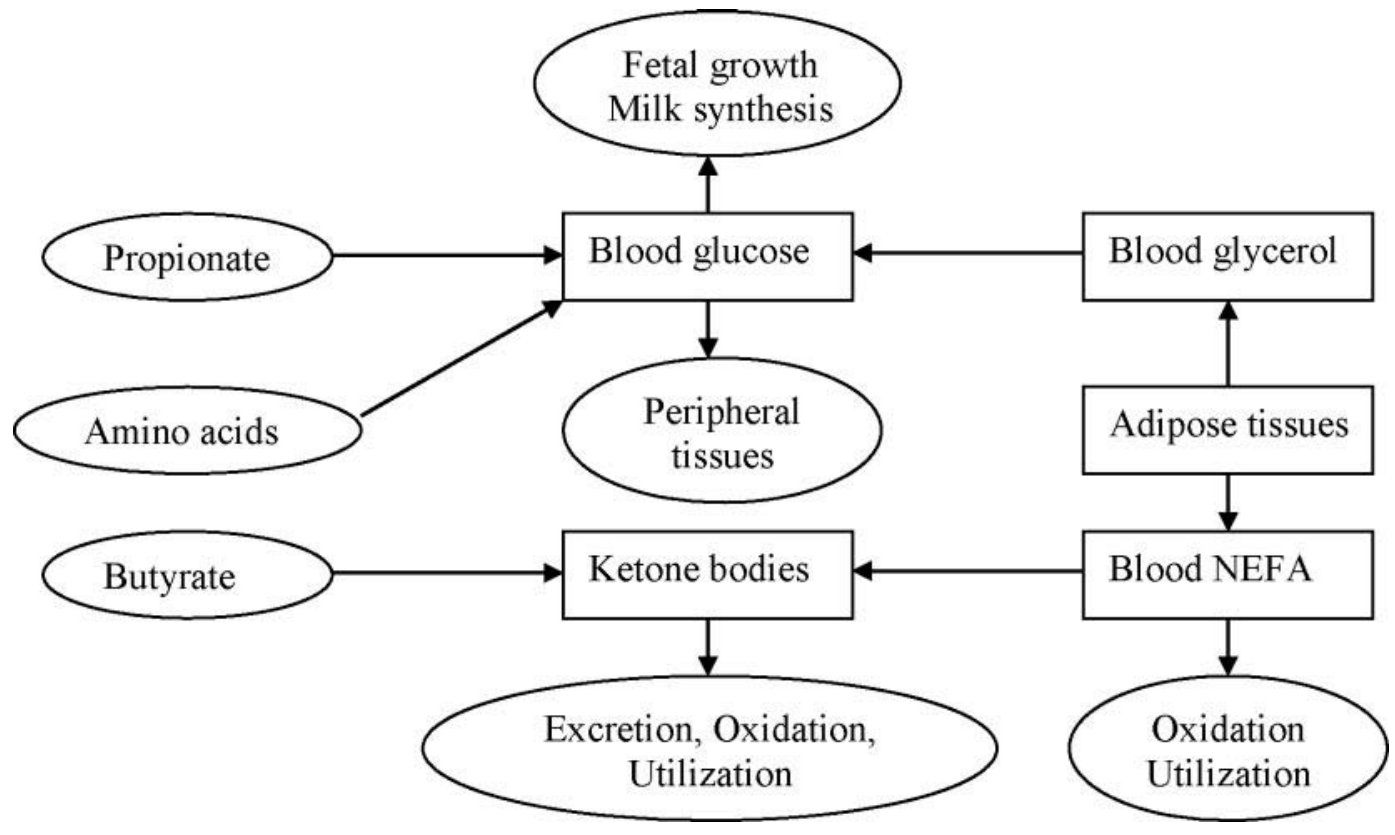

Figure 1. A model of glucose and lipid metabolism in periparturient cows. 
Table 2. Model equations

\begin{tabular}{|c|c|}
\hline Prediction & Equation \\
\hline 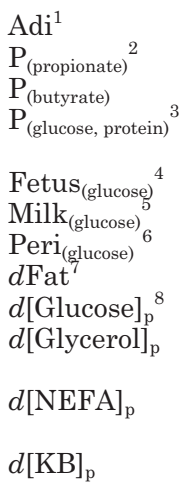 & 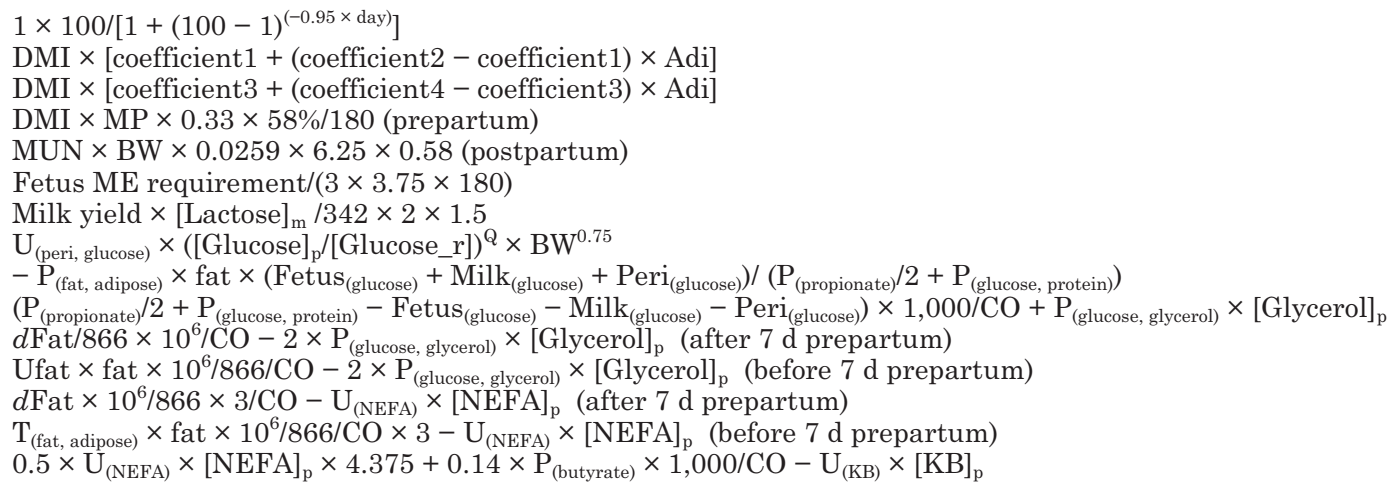 \\
\hline
\end{tabular}

${ }^{1}$ Day $=$ days since diets had been changed.

${ }^{2}$ Coefficients 1 and $3=$ propionate and butyrate produced by $1 \mathrm{~kg}$ of nonlactating-cow diet; coefficients 2 and $4=$ propionate and butyrate produced by $1 \mathrm{~kg}$ of concentrate diet; VFA production by $1 \mathrm{~kg}$ of DM fermented in rumen calculated by Murphy's model (Murphy et al., 1982).

${ }^{3} \mathrm{MP}=\mathrm{MP}$ estimated by NRC (2001); $0.33=$ percentage of MP for catabolism; $58 \%=$ catabolism of $100 \mathrm{~g}$ of protein gives $58 \mathrm{~g}$ of glucose (Dukes, 1993). MUN $\times$ BW $\times 0.0259$ = estimation of urinary nitrogen excretion (Kohn et al., 2002).

${ }^{4}$ Fetus ME requirement estimated by NRC (2001); one-third of energy requirement for fetus provided by glucose (NRC2001); $1 \mathrm{~g}$ of glucose gives rise to $3.75 \mathrm{kcal}$ of energy.

${ }^{5}[\text { Lactose }]_{\mathrm{m}}=$ lactose concentration in milk; mammary glucose requirement is 1.5 times that required for lactose synthesis (Cant et al., 1993 ; Mackle et al., 2000).

${ }^{6}[$ Glucose_r] $=3.15 \mathrm{mM}$ as reference concentration of plasma glucose. $\mathrm{Q}=3$ (prepartum), $\mathrm{Q}=4$ (postpartum).

${ }^{7} d$ Fat was set to zero before $d 7$ prepartum.

${ }^{8} \mathrm{CO}=$ cardiac output $=472 \mathrm{~L} \times \mathrm{BW}^{0.75} \times \mathrm{d}^{-1}$ (Baldwin, 1995). $\mathrm{P}_{\text {(glucose, glycerol) }}=0.5=$ plasma glycerol was completely utilized by gluconeogenesis.

fat) and glucose deficiency (ratio of glucose demand for fetal growth, milk synthesis, and peripheral tissue utilization to glucose supply from feed per day). The model assumed that lipolysis and lipogenesis were in equilibrium before $\mathrm{d} 7$ prepartum and that lipogenesis had completely ceased in adipose tissues after $\mathrm{d} 7$ prepartum. The change in plasma NEFA was expressed as a balance between its utilization and fat mobilization. The model assumed that the rate of NEFA utilization (mmol/d per mmol of NEFA) followed first-order kinetics. The KB concentrations depended on the ketogenesis rates from NEFA and butyrate, and the rate of $\mathrm{KB}$ utilization $(\mathrm{mmol} / \mathrm{d}$ per $\mathrm{mmol}$ of $\mathrm{KB})$. The rate of $\mathrm{KB}$ utilization was represented as a first-order reaction in the model.

Parameters Derived from Published Literature. The rate of propionate production from rumen fermentation was calculated from DMI and feed composition (Murphy et al., 1982). More recent equations for predicting VFA production (Dijkstra et al., 1992; Bannink et al., 2000) were not chosen because those equations require more inputs such as rumen volume and fractional passage rates. The rumen adaptation index in the model represented the shift to grain fermentation in rumen from the high-forage diet of the nonlactating period. The propionate-producing microbes were as- sumed to increase when the transition or lactation diet was fed. The shift depends mainly on 2 factors: substrate availability and the microbial population. The index was derived from the logistic growth equation (France and Thornley, 1984): $d \mathrm{~W} / d t=\mathrm{k} \times \mathrm{W} \times \mathrm{S}$, where $\mathrm{W}$ is microbial population at time of $\mathrm{t} ; \mathrm{k}$ is a growth rate constant; $\mathrm{S}$ is substrate availability for microbial growth, which after integration and rearrangement gives $\mathrm{W}=\mathrm{W}_{0} \times \mathrm{W}_{\mathrm{f}} /\left[\mathrm{W}_{0}+\left(\mathrm{W}_{\mathrm{f}}-\mathrm{W}_{0}\right)^{-u t}\right]$, where $\mathrm{W}_{0}=$ $1 ; \mathrm{W}_{\mathrm{f}}=100 ; u=0.95$. The values for $\mathrm{W}_{0}$ and $\mathrm{W}_{\mathrm{f}}$ were assigned only to represent the change in propionateproducing microbes. The coefficient $u$ corresponds to the rate of adaptation of rumen microbes to the highgrain diet, and it was assigned the value 0.95 , which corresponds to a 10-d adaptation period. The 10-d adaptation period is based on the fact that the potential for digestive upsets from rapid fermentation of starch requires gradual introduction of high concentrate diets over a period of at least $10 \mathrm{~d}$ (Coe et al., 1999).

All of the propionate produced from starch in the rumen was assumed to be available for gluconeogenesis in the animal. In reality, the rumen epithelium could metabolize 40 to $60 \%$ of propionate (Parker, 1990). Products of metabolism are energy, $\mathrm{CO}_{2}$, lactate, and alanine, the last 2 of which are glucogenic. The liver could take up $90 \%$ or more of the absorbed propionate 
Table 3. The mean values of the parameters $(\mathrm{SD})^{1}(\mathrm{n}=28)$

\begin{tabular}{|c|c|c|c|c|}
\hline Parameter $^{2}$ & Prepartum (SD) & Postpartum (SD) & $\mathrm{SED}^{3}$ & $P$-value ${ }^{4}$ \\
\hline $\begin{array}{l}\mathrm{U}_{\text {(peri, glucose) }} \\
\mathrm{T}_{\text {(fat, adipose) }} \\
\mathrm{P}_{\text {(fat, adipose) }} \\
\mathrm{U}_{(\text {(NEFA) }} \\
\mathrm{U}_{\text {(KB) }}\end{array}$ & $\begin{array}{l}0.039(0.0166) \\
0.009(0.0031) \\
0.012(0.0057) \\
0.188(0.07892) \\
0.31(0.118)\end{array}$ & $\begin{array}{l}0.042(0.0276) \\
\quad- \\
0.015(0.0059) \\
0.224(0.0775) \\
0.47(0.167)\end{array}$ & $\begin{array}{l}0.0067 \\
-\overline{0} \\
0.0013 \\
0.0245 \\
0.045\end{array}$ & $\begin{array}{r}0.47 \\
\overline{0} \\
0.04 \\
0.16 \\
<0.01\end{array}$ \\
\hline \multicolumn{5}{|c|}{$\begin{array}{l}\left.{ }^{1} \text { Standard deviation for parameters fit among } 28 \text { cows from the developmental data set (Guo et al., } 2007\right) \text {. } \\
{ }^{2} \mathrm{U}_{\text {(peri, glucose) }}=\text { utilization rate of glucose by peripheral tissues }\left(\mathrm{mol} / \mathrm{d} \text { per } \mathrm{kg} \text { of } \mathrm{BW}^{0.75}\right) ; \mathrm{T}_{\text {(fat, adipose) }}=\text { turnover } \\
\text { rate of adipose tissues before } 7 \mathrm{~d} \text { prepartum }\left(\mathrm{kg} / \mathrm{d} \text { per } \mathrm{kg} \text { of body fat); } \mathrm{P}_{(\text {fat, adipose) }}=\text { mobilization rate of fat }\right. \\
\text { from adipose tissues }\left(\mathrm{kg} / \mathrm{d} \text { per kg of body fat); } \mathrm{U}_{(\mathrm{NEFA})}=\text { utilization rate of NEFA (mmol/d per mmol of NEFA); }\right. \\
\text { and } \mathrm{U}_{(\mathrm{KB})}=\text { utilization rate of ketone bodies }(\mathrm{mmol} / \mathrm{d} \text { per mmol of } \mathrm{KB}) \text {. } \\
{ }^{3} \mathrm{SED}=\text { standard error of difference. }\end{array}$} \\
\hline
\end{tabular}

(Kristensen and Harmon, 2004). Although this assumption regarding propionate available for gluconeogenesis would lead to an overestimate, we are likely to have underestimated glucose available from the digestion of bypass starch in the small intestine. At least $90 \%$ of starch in small grains is fermentable in the rumen, up to $40 \%$ of corn starch could escape rumen fermentation (Orskov, 1986). Quantities of starch disappearing in the small intestine vary with digestibilities ranging from 10 to $96 \%$ (Harmon, 1992). The variability of the available information makes it difficult to incorporate the above quantitative information into the model. For model simplicity, the contribution of the escape starch to glucose production was not considered and all the propionate was assumed to be converted into glucose by the liver in the model. The rate of butyrate production was estimated in the same way as the rate of propionate production in the model (Table 2).

The rate of gluconeogenesis from protein was estimated by the amount of catabolized protein. Catabolism of $100 \mathrm{~g}$ of protein was assumed to give rise to $58 \mathrm{~g}$ of glucose (Dukes, 1993). Before parturition, one-third of metabolizable protein was catabolized (NRC, 2001) assuming that all the metabolizable protein came from feed. After parturition some of the catabolized protein came from endogenous sources (Komaragiri et al., 1998). The rate of catabolized protein postpartum was estimated from urinary nitrogen excretion as Urinary $\mathrm{N}(\mathrm{g} / \mathrm{d})=0.026 \times \mathrm{BW}(\mathrm{kg}) \times \mathrm{MUN}(\mathrm{mg} / \mathrm{dL})(\mathrm{Kohn}$ et al., 2002). The equation is based on renal physiology throughout lactation. However, overestimation of postpartum protein catabolism may result from origination of urinary nitrogen from rumen ammonia. Carbohydrate sources and ratios of carbohydrate to protein fractions in the diets could influence the amount of urea from rumen ammonia. The coefficient ( $58 \mathrm{~g}$ of glucose per $100 \mathrm{~g}$ of protein) is also associated with large variation (Dukes, 1993). Estimation of gluconeogenesis from protein could be improved once additional information is available.
The rate of glucose utilization for fetal growth was derived from the energy requirement, which was estimated from calf birth weights according to NRC (2001). In the nonlactating period, about 775 of $2,336 \mathrm{kcal} / \mathrm{d}$ of energy required for fetal growth came from glucose and lactate (Bell, 1995). Presumably, one-third of the energy requirement was provided in the form of glucose.

The mammary glucose requirement was estimated from milk yield and lactose concentrations. Lactose production in milk accounted for 55 to $78 \%$ of the glucose uptake by the mammary gland (Cant et al., 1993; Mackle et al., 2000). In the model, the efficiency of glucose uptake for lactose synthesis was assumed to be $66.5 \%$, which is the average of 55 and $78 \%$.

Parameters Determined by Best Fit. The parameters listed in Table 3 were optimized by a modified Powell algorithm for each individual cow to find the minimum sum of squares for deviations between observed data and model predictions. The model predictions for the response variables were calculated using the DMI, feed composition, calf birth weight, milk yield, and milk components from the development data set as the model input. The initial values for the response variables were adapted from the pretreatment measurements from the developmental data set. In the developmental data, body fat content was not actually measured, but was estimated from body weight and BCS (NRC, 2001).

The model was simulated and fit using Scientist software (Scientist Software, 1995, Salt Lake City, UT). Two criteria (Neal and Thornley, 1983) were applied in fitting parameters to the model. First, the predictions of the model must approximate observed data. Second, biological realism should not be violated.

\section{Statistical Analysis}

The mean parameter values for all cows (Table 3 ) in the developmental data were used to calculate model predictions, and compared against observations. A 
mean bias for model predictions was declared if residual (observed - predicted) values were significantly different from zero. Linear bias for model predictions was evaluated by regression analysis for residuals against model predictions. Root mean square prediction error (RMSPE) was calculated from the following equation (Bibby and Toutenburg, 1977): RMSPE = square root of $\left[\Sigma(\text { observed }- \text { predicted })^{2} / \mathrm{n}\right]$. Statistical significance was declared at $P<0.05$.

\section{RESULTS}

Parameter values are shown in Table 3. The rates of fat mobilization and KB utilization postpartum were significantly greater than those prepartum $(P<0.05$ and $P<0.01$, respectively).

The predicted values for plasma glucose, glycerol, NEFA, and KB followed a similar pattern to the data observed in the animal trial (Figure 2). The agreement between predicted and observed KB was further demonstrated in a ketotic cow as an extreme case. One cow was diagnosed with clinical ketosis and her data were excluded from data analysis in the previous paper (Guo et al., 2007) and from model parameterization in the present paper. At d 2 and 3 postpartum, she was administrated intravenously with $1,000 \mathrm{~mL}$ of dextrose
(50\%). The KB concentration increased from 0.6 to 0.9 $\mathrm{m} M$, and then decreased from 0.9 to $0.25 \mathrm{~m} M$ after the dextrose treatment had stopped. The agreement between observed and predicted values for KB concentrations is presented in Figure 3.

Residual analysis for the developmental data was conducted by comparing model predictions with residuals (observed - predicted) for the response variables (Figures 4 and 5). The model overpredicted glycerol concentrations with a mean bias of $0.001 \mathrm{mM}(P<0.05$; Table 4). No mean bias or linear bias was found for body fat predictions $(P>0.05)$. Linear biases for glucose, glycerol, NEFA, and KB were observed $(P<0.05)$. The standard error of model predictions was $19,43,48$, 36 , and $4 \%$ of mean predictions for glucose, glycerol, NEFA, KB, and body fat predictions.

According to the model prediction, peripheral tissues consumed more glucose in the last $21 \mathrm{~d}$ of gestation compared with the first 21 DIM with a surge around parturition. Glucose consumed by peripheral tissues was greater for the treatment cows from d 15 prepartum to $\mathrm{d} 10$ postpartum compared with the control cows (Figure 6). The predicted glucose balances differed in the patterns between the treatment and control groups (Figure 7). Before parturition, the treatment cows had a greater glucose balance. However, after partu-
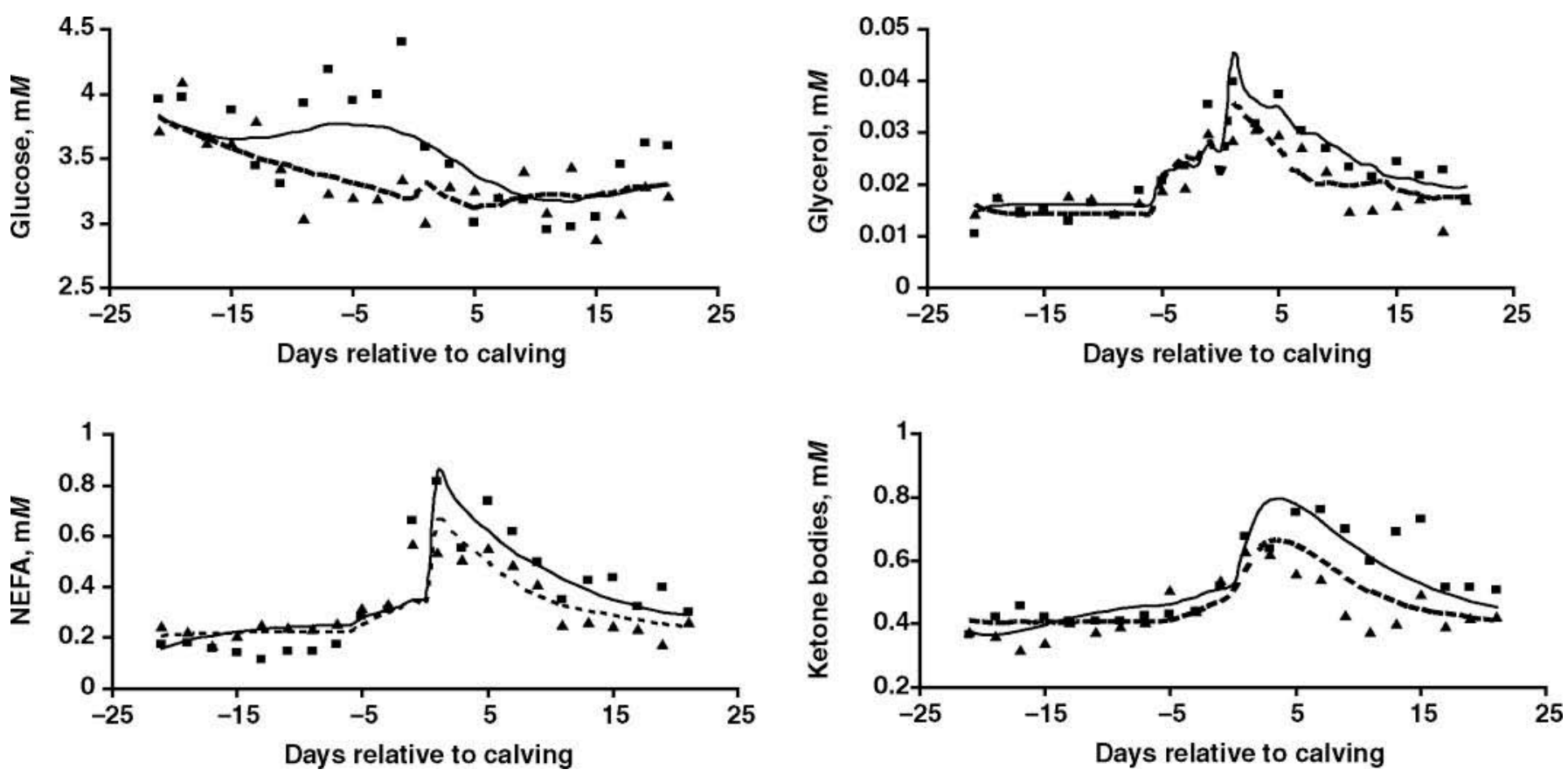

Figure 2. Time course of blood metabolites during periparturient period. $\boldsymbol{\Delta}=$ observed values in the control group; $\boldsymbol{\|}=$ observed values in the treatment group; --.---- = predicted values for the control group; _ _ predicted values for the treatment group. The cows in the control group were fed a diet for dry cows before calving and a lactation diet postcalving. The cows in the treatment group were fed a transition diet in the last $17 \mathrm{~d}$ of gestation and the first $14 \mathrm{~d}$ of lactation. 


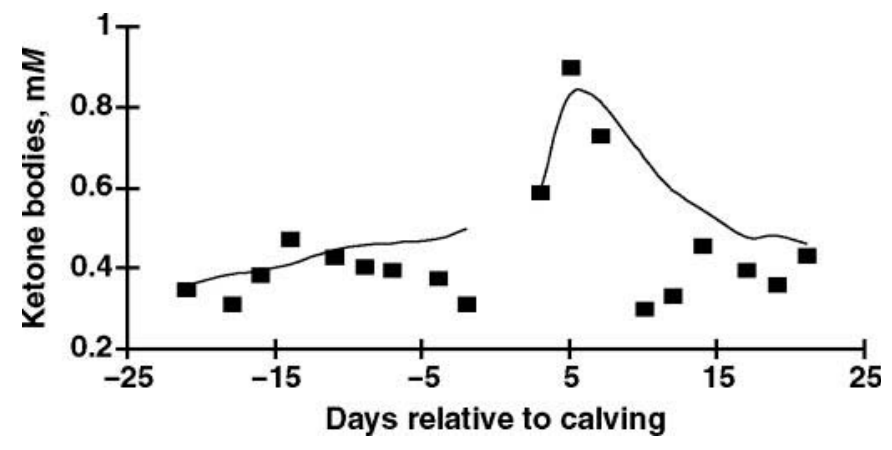

Figure 3. Time course of total plasma ketone bodies in a ketotic cow during periparturient period. $\square=$ observed; $-=$ model predicted. The cow was diagnosed with clinical ketosis and given 1,000 $\mathrm{mL}$ of $50 \%$ dextrose at $\mathrm{d} 2$ and 3 postpartum. Data around parturition were missing due to severe weather conditions.

rition the control cows had a greater glucose balance compared with the treatment cows. According to the model prediction, glycerol provided 12 and $17 \%$ of the glucose demand in the control and treatment groups, respectively, and the treatment group mobilized more glycerol for gluconeogenesis from adipose tissues after parturition compared with the control (Figure 8).
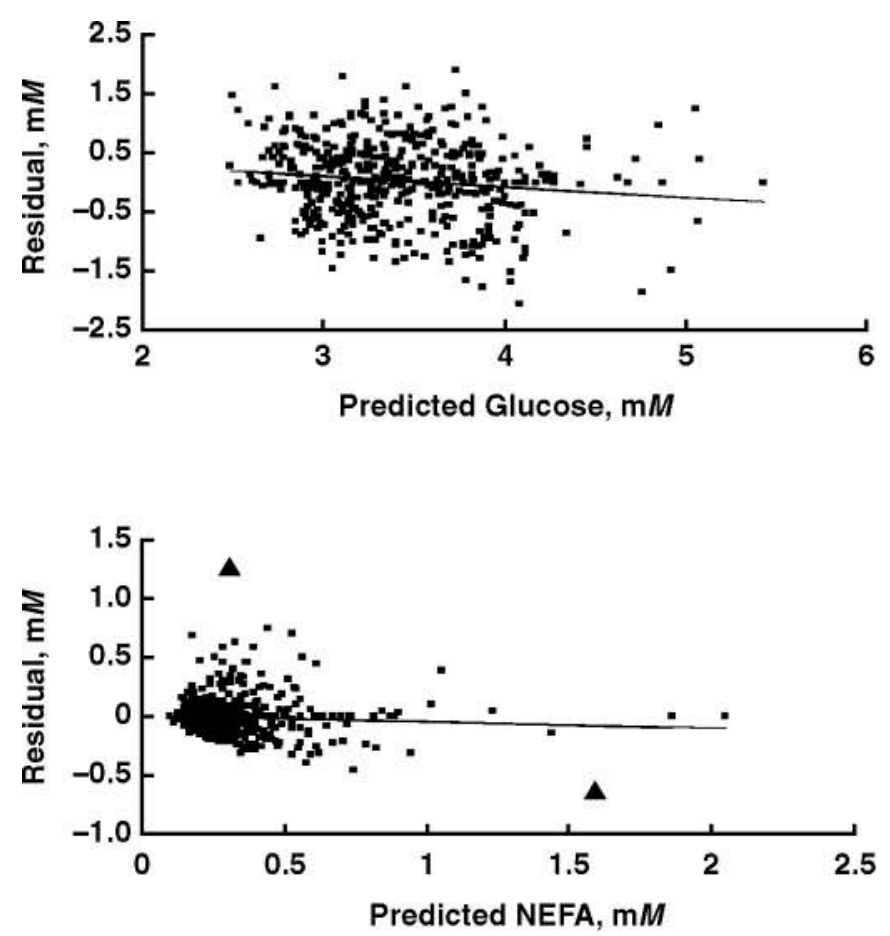

\section{DISCUSSION}

\section{Physiological Basis of the Model}

The model assumed that glucose was the limiting nutrient during the periparturient period. In ruminants, glucose supply is met mainly by gluconeogenesis, an energetically inefficient pathway compared with hydrolysis of starch in nonruminant animals. Fetal growth increased dramatically in late gestation (House and Bell, 1993), and oxidation of lactate and glucose account for up to $60 \%$ of fetal respiration in lambs (Hay et al., 1983). After parturition, the demand for glucose is increased greatly by milk synthesis. Lactate utilization for gluconeogenesis represents recycling of carbon because some of circulating lactate is formed during catabolism of glucose by peripheral tissues (Drackley et al., 2001). Lactate from partial catabolism of propionate by visceral epithelial tissues was accounted for by the assumption that propionate was completely used for gluconeogenesis in the model. The primary function of body protein is by no means to preserve glucose precursors, although amino acids (except for leucine and lysine) are glucogenic. Between 2 and 5 wk postpartum cows mobilized only $12 \mathrm{~kg}$ of body protein (Komaragiri et al., 1998), while part of mobilized
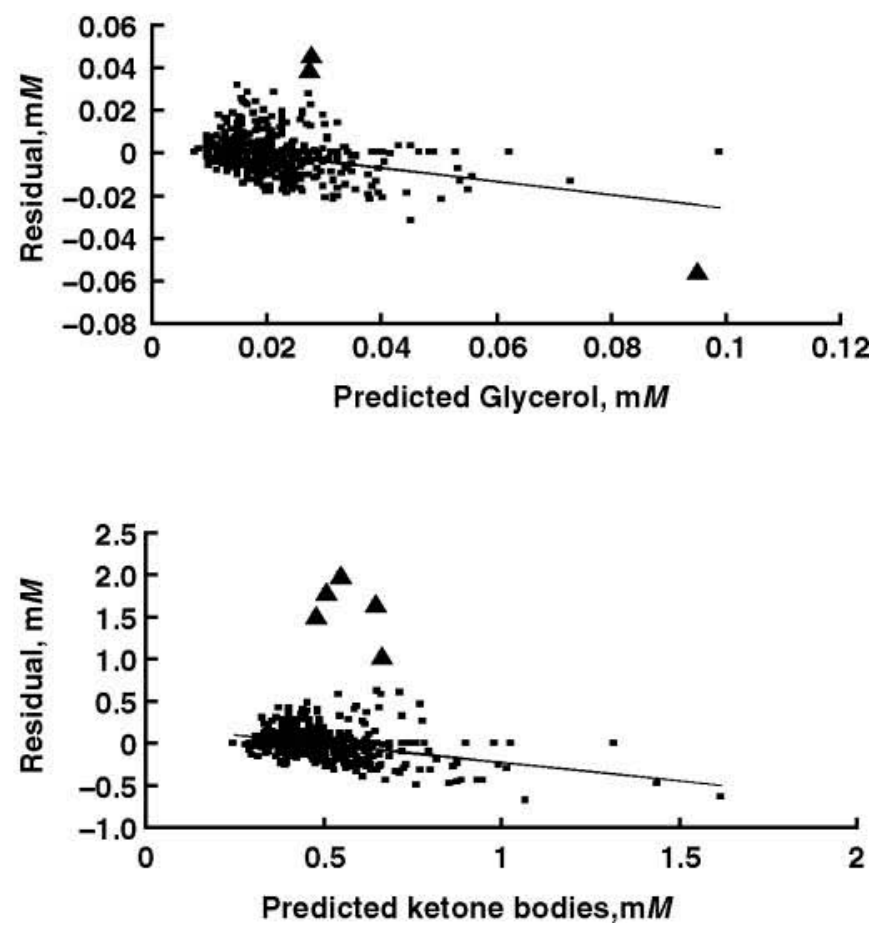

Figure 4. Plots of residual values against model predictions. Residual = observed - predicted. Data points with $\boldsymbol{\Delta}$ were identified as outliers and were not used by regression analysis. The outliers were detected with 3 regression diagnostic statistics: jackknife residuals, leverages, and Cook's distance (Kleinbaum et al., 1998). Glucose: $y=0.65-0.18 \times x$; glycerol: $y=0.006-0.313 \times x$; NEFA: $y=0.007-0.054$ $\times \mathrm{x}$; ketone bodies: $\mathrm{y}=0.21-0.44 \times \mathrm{x}$. 


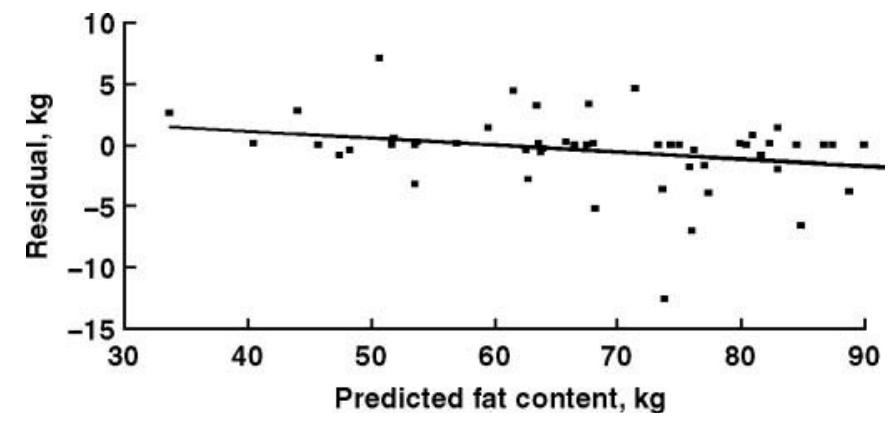

Figure 5. Plot of residual values against model predicted body fat. Residual $=$ observed - predicted. $\mathrm{y}=3.48-0.06 \times \mathrm{x}$.

protein must be excreted as milk protein. Bauman and Elliot (1983) concluded that over the period up to peak lactation the contribution of mobilized tissue protein to gluconeogenesis is small. Depressed feed intake around parturition (Ingvartsen and Andersen, 2000) could further exaggerate glucose deficiency. Thus, glucose deficiency could play a critical role in the orchestration of the entire metabolism in periparturient cows.

\section{Glucose}

Glucose utilization by peripheral tissues is regulated mainly by plasma insulin, tissue responses to insulin (Petterson et al., 1993), and glucose availability. The exact mathematical relationship between glucose utilization and these 3 factors was beyond the scope of this model. An aggregate equation was selected to approximately represent that relationship in the model (Table 2). In the equation, the dependence of peripheral consumption on glucose availability was defined as the ratio of plasma glucose concentrations to a reference concentration $(3.15 \mathrm{~m} M)$. The power ' $\mathrm{Q}$ ' to that ratio was assigned to 3 prepartum and to 4 postpartum, which provided the best fit of the data. The biological meaning of the power ' $Q$ ', which is not known, is presumably related to endocrine status and tissue sensi-

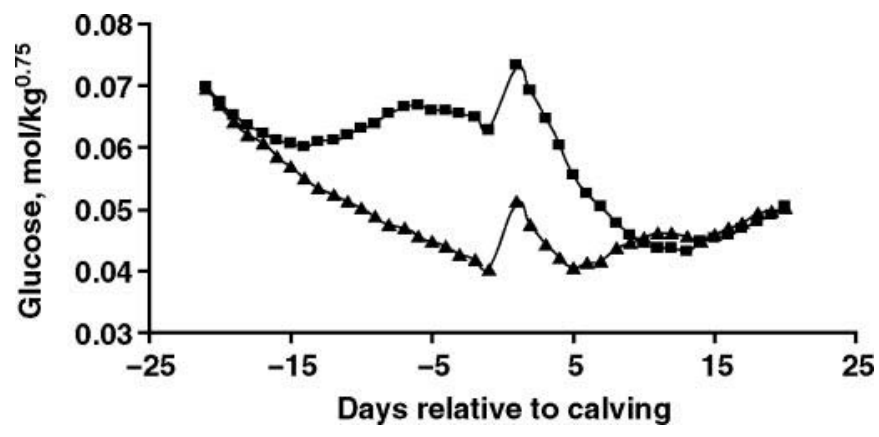

Figure 6. Model prediction for glucose consumed by the peripheral tissues. $\boldsymbol{\Delta}=$ control group; $\boldsymbol{\|}=$ treatment group. The cows in the control group were fed a diet for dry cows before calving and a lactation diet postcalving. The cows in the treatment group were fed a transition diet in the last $17 \mathrm{~d}$ of gestation and the first $14 \mathrm{~d}$ of lactation.

tivity to hormones. Although the equation of glucose utilization by peripheral tissues did not fully represent the biological mechanism, the model predicted blood glucose concentrations without mean bias. The linear bias, although statistically significant, could not be of biological importance because the maximum prediction error resulting from the linear bias is only $0.31 \mathrm{mM}$ $[-0.31=0.65-0.18 \times 5.43-(-0.02)$, where 5.43 is the maximum glucose concentration observed in the development data set, -0.02 is the mean bias, and the rest of equation is from the regression analysis in Figure 3].

The model predicted that more glucose was consumed by peripheral tissues prepartum compared with the postpartum period, with a surge around parturition. A difference in peripheral glucose utilization between the treatment and control groups was also predicted by the model. Before parturition the difference may result from the greater glucose availability in the treatment groups compared with the control group as reported previously (Guo et al., 2007). Feeding a high-concentrate diet during the late gestation period increased plasma insulin concentrations, and this effect carried over into

Table 4. Residual analysis for the developmental data set (from 28 cows)

\begin{tabular}{|c|c|c|c|c|c|c|}
\hline Prediction $^{1}$ & $\mathrm{n}$ & Mean & $\mathrm{RMSPE}^{2}$ & $\mathrm{CV}, \%$ & Mean bias ${ }^{3}$ & Linear bias ${ }^{4}$ \\
\hline$[\text { Glucose }]_{\mathrm{p}}, \mathrm{m} M$ & 472 & 3.41 & 0.663 & 19 & -0.02 & $-0.18^{*}$ \\
\hline [Glycerol $]_{\mathrm{p}}, \mathrm{m} M$ & 469 & 0.022 & 0.009 & 43 & $-0.001 *$ & $-0.313^{*}$ \\
\hline$[\mathrm{NEFA}]_{n}, \mathrm{~m} M$ & 470 & 0.33 & 0.162 & 48 & -0.01 & $-0.054^{*}$ \\
\hline$[\mathrm{KB}]_{\mathrm{p}}, \mathrm{m} M$ & 467 & 0.49 & 0.180 & 36 & -0.02 & $-0.44^{*}$ \\
\hline Fat, kg & 56 & 69.2 & 2.96 & 4 & -0.5 & -0.06 \\
\hline
\end{tabular}

${ }^{1}$ Prediction of plasma concentrations of glucose, glycerol, NEFA and ketone bodies (KB), respectively. Fat = body fat content.

${ }^{2}$ Root mean square prediction error.

${ }^{3}$ Mean bias $=$ mean observation - mean prediction .

${ }^{4}$ Linear bias $=$ slope of regression analysis for residuals against model predictions.

${ }^{*} P<0.05$. 
early lactation (Holcomb et al., 2001). The carryover effect may be responsible for the difference between the treatment and control groups after parturition, as the model predicted. According to the model predictions, the amount of glucose consumed by peripheral tissues ranged from 0.04 to $0.07 \mathrm{~mol} / \mathrm{d}$ per $\mathrm{kg}$ of $\mathrm{BW}^{0.75}$ prepartum, and from 0.04 to $0.05 \mathrm{~mol} / \mathrm{d}$ per $\mathrm{kg}$ of $\mathrm{BW}^{0.75}$ postpartum in the control cows. A turnover rate of glucose in ruminants under basal conditions had been reported by Baldwin (1995) between 0.03 and $0.05 \mathrm{~mol} / \mathrm{d}$ per $\mathrm{kg}$ of $\mathrm{BW}^{0.75}$. Compared with the data by Baldwin (1995), the overprediction may be caused by 2 factors: first, the cows were not under the basal condition; second, during the nonlactating period, glucose may be used to produce glycerol moiety for triglyceride synthesis in adipose tissues.

\section{Glycerol}

A mean bias was observed for glycerol concentration predictions; however, the absolute value was only $0.001 \mathrm{~m} M$, which is biologically insignificant relative to the glycerol concentrations under the basal condition. A linear bias was also observed for glycerol predictions. The linear bias was mainly caused by a few of the residuals when glycerol predictions were above the normal range. Blood glycerol can be directly incorporated into galactose for lactose synthesis in the mammary gland (Sunehag et al., 2002). The linear bias for glycerol predictions may be caused by the synthesis of galactose from glycerol, which was not considered in the model. Contribution of glycerol to gluconeogenesis ranged from 12 to $17 \%$ as predicted by the current model, which agrees well with the range from 15 to $20 \%$ of the glucose demand at $4 \mathrm{~d}$ postpartum (Bell, 1995).

Removal of glycerol by the liver (Reynolds et al., 2003) and gluconeogenesis (Greenfield et al., 2000) increases greatly after parturition. The model assumed that glycerol released from fat mobilization was completely utilized for glucose synthesis. Contribution of glycerol to gluconeogenesis depended on the concentrations of plasma glycerol that resulted from fat mobilization. Fat mobilization was determined by glucose deficiency in the model. The model predictions for glycerol concentrations agreed well with the observed values from the developmental data (Figure 2).

\section{Body Fat Content}

The result of model parameterization showed that the postpartum rate of fat mobilization was greater than the prepartum rate. The difference in the rates of fat mobilization prepartum and postpartum is in agree-

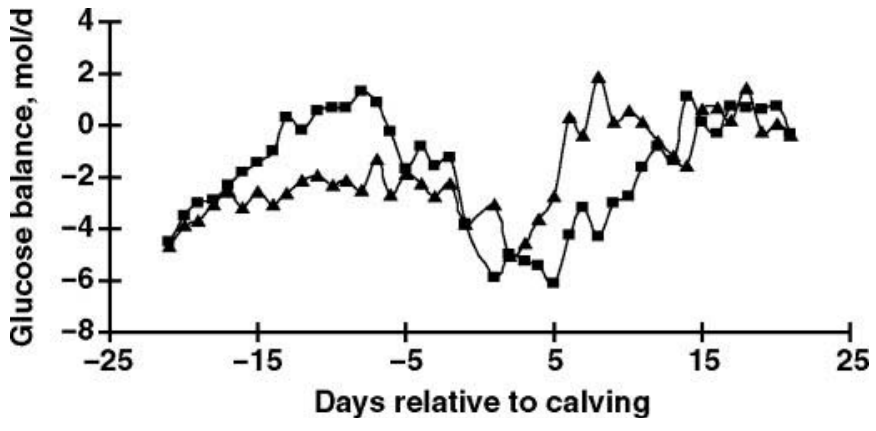

Figure 7. Estimated glucose balances during the periparturient period. $\boldsymbol{\Delta}$ = control group; $\boldsymbol{\nabla}=$ treatment group. The cows in the control group were fed a diet for dry cows before calving and a lactation diet postcalving. The cows in the treatment group were fed a transition diet in the last $17 \mathrm{~d}$ of gestation and the first $14 \mathrm{~d}$ of lactation. Glucose balances were calculated by propionate from feed, catabolized protein, fetus growth, milk synthesis, and peripheral tissue requirement.

ment with the fact that the change in the endocrine profiles and sensitivities to hormones greatly enhanced fat mobilization in early lactation compared with late gestation (Bell, 1995).

The contribution of glucose precursor from fat mobilization is predicted in Figure 8. According to the model, $270 \mathrm{~g}$ of glucose could be provided from $2.5 \mathrm{~kg}$ of fat when maximum fat mobilization occurred. This amount of glucose is small relative to total supply from feed; however, the importance of this amount should not be inconsequential. In the field, bolus i.v. administration of $500 \mathrm{~mL}$ of $50 \%$ dextrose solution (about $250 \mathrm{~g})$ is a common therapy for ketosis. Drenching of propylene glycol $(250 \mathrm{~g} / \mathrm{d})$ is also effective in treating ketosis for postpartum cows. These small doses provide a similar amount of glucose as the amount of glycerol from fat mobilization, but have a consequential effect

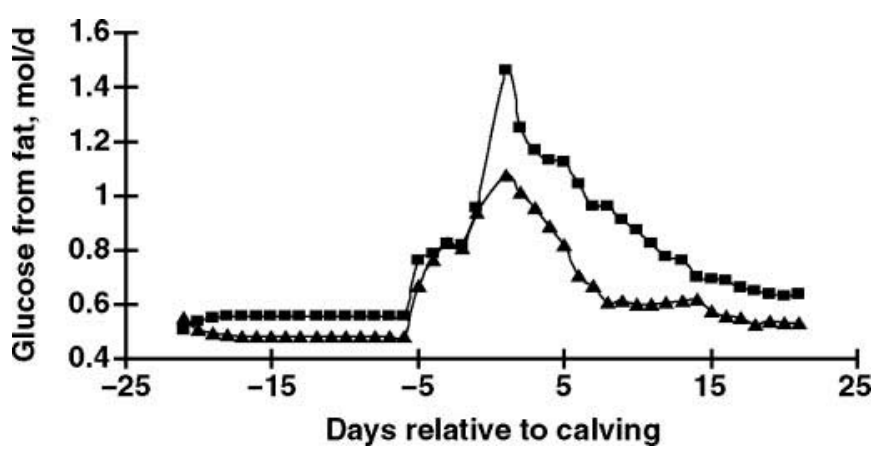

Figure 8. Model prediction for the contribution of glycerol from fat mobilization to glucose synthesis in the periparturient cows. $\boldsymbol{\Delta}$ = control group; $\mathbf{\square}=$ treatment group. The cows in the control group were fed a diet for dry cows before calving and a lactation diet postcalving. The cows in the treatment group were fed a transition diet in the last $17 \mathrm{~d}$ of gestation and the first $14 \mathrm{~d}$ of lactation. 
on reestablishing glycemia and reducing blood ketone body concentrations in ketotic cows. The present model demonstrated that the contribution of glucose precursor from fat mobilization should be considered to explain the dynamics of glucose metabolism in periparturient cows after the glucose supply from feed and gluconeogenesis from body protein mobilization has been accounted for. Thus, glycerol from fat mobilization may be an important gluconeogenic precursor as the cow adapts to lactation (Drackley et al., 2001).

The actual a mount of fat mobilization could be underestimated in the present model. The observed values for body fat content used for model parameterization were estimated from BW and BCS. Changes in BW after parturition could easily be masked by the mass increase in the gastrointestinal tract and its contents. Variation in body condition would not be detected within a short period by BCS, which is a crude estimate. In addition, calculation of glucose precursors from fat mobilization is also underestimated. According to the model, glycerol from $1 \mathrm{~kg}$ of triglyceride provides about $110 \mathrm{~g}$ of glucose, which means that an extra $1 \mathrm{~kg}$ of milk requires $3 \mathrm{~kg}$ more fat to be mobilized. In fact, oxidation of odd- and branched-chain fatty acids produces propionyl-CoA, which could be either completely oxidized or converted into glucose. Quantitative information on metabolic fate of the propionyl-CoA is limited. The total proportions of odd-number fatty acids represented 3.7 to $4.2 \%$ of total fatty acids (Elias-Calles et al., 1997), and the proportion of branched-chain fatty acids was about $2 \%$ (Duncan and Garton, 1978). Thus, it is difficult to incorporate metabolism of odd- and branched-chain fatty acids into the current model.

\section{NEFA}

Endocrine status differs greatly before and after parturition. However, according to the model parameterization, the prepartum rate of NEFA utilization was not significantly different from the postpartum rate, probably because NEFA metabolism in the liver of dairy cows is less responsive to hormonal control than is the metabolism in laboratory species (Cadorniga-Valino et al., 1997), and there is no preferential direction of NEFA to the liver at the expense of other tissue (Drackley et al., 2001). Uptake and oxidation of NEFA by the liver and extrahepatic tissues are directly related to plasma concentrations (Pethick et al., 1983). Thus, the model assumed the rate of NEFA utilization followed firstorder kinetics and expressed in term of millimoles per day per millimole of NEFA. In the model, the postpartum rate of NEFA utilization rate was $0.2236(\mathrm{mmol} / \mathrm{d}$ per mmol of NEFA). With this value, the predicted whole-body utilization for the cows at wk 4 postpartum studied by Reynolds et al. (1988) would be $4.4 \mathrm{~mol} / \mathrm{d}$ : $4,400 \mathrm{mmol} / \mathrm{d}=0.2236(\mathrm{mmol} / \mathrm{d}$ per mmol, NEFA utilization rate $) \times 0.328(\mathrm{~m} M$, NEFA concentration $) \times 472$ $\left(\mathrm{L} / \mathrm{BW}^{0.75}\right.$, cardiac output $) \times 640^{0.75}\left(\mathrm{~kg}\right.$ of $\left.\mathrm{BW}^{0.75}\right)$. Given that the percentage of cardiac output flowing through the liver was 31\% (Huntington et al., 1990) and that the measured net uptake of NEFA by liver was 60.8 $\mathrm{mmol} / \mathrm{h}$ (Reynolds et al., 1988), the NEFA utilization by the whole body would be $4.7 \mathrm{~mol} / \mathrm{d}(4,700 \mathrm{mmol} / \mathrm{d}=$ $60.8 \mathrm{mmol} / \mathrm{h} \times 24 \mathrm{~h} / \mathrm{d} \div 31 \%$ ), which agreed well with the current model prediction. The linear bias, although statistically significant, could not be of biological importance as the maximum prediction error resulting from the linear bias was only $0.09 \mathrm{~m} M[-0.09=0.007$ $-0.054 \times 2.05-(-0.01)]$, where 2.05 is the maximum NEFA concentration observed in the development data set, -0.01 is the mean bias, and the rest of equation is from the regression analysis in Figure 3.

\section{Ketone Bodies}

In the model, the prepartum rate of $\mathrm{KB}$ utilization was significantly different from the postpartum rate. The model predicted that the pre- and postpartum rates of $\mathrm{KB}$ utilization rates were 0.31 and $0.47 \mathrm{mmol} / \mathrm{d}$ per $\mathrm{mmol} \mathrm{KB}$ respectively, corresponding to $7.5 \mathrm{~mol} / \mathrm{d}$ in late gestation and to $17.5 \mathrm{~mol}$ at d 5 postpartum in the control cows. Extrapolated from the published data in sheep when corrected for BW, the cows in the control group would utilize $4.6 \mathrm{~mol}$ of $\mathrm{KB}$ per day in late gestation, and $12.5 \mathrm{~mol}$ of $\mathrm{KB}$ at d 5 postpartum according to Heitmann et al. (1987). The utilization rates of KB in the model were slightly greater compared with the published data, probably because the data by Heitmann et al. (1987) did not include acetone metabolism. The quantitative information on acetone metabolism is extremely limited for dairy cows. In rats, after administration of radiolabeled acetone by stomach tube or by injection, demonstrable amounts of radioactivity were recovered in glycogen, urea, cholesterol, fatty acids, amino acids, and heme, and a substantial amount of radiolabeled carbon was recovered in exhaled carbon dioxide (Price and Rittenberg, 1950).

There is a significant linear bias for $\mathrm{KB}$ predictions in the model. The bias may result from acetone metabolism as discussed above. In addition, as KB concentrations increase, an increased proportion of $\mathrm{KB}$ is lost in the urine or via breathing. The ratio of $\mathrm{KB}$ excreted via urine $(\mathrm{mg} / \mathrm{d})$ to blood concentration $(\mathrm{mg} / \mathrm{dL})$ is $<42$ in humans under normal conditions, whereas the ratio is about 56 in an untreated diabetic patient (Nelson et al., 2000). Another possibility may come from peroxisomal oxidation, which is not considered in the model. The peroxisomal pathway, an auxiliary pathway to 
mitochondrial oxidation, may be induced when hepatocellular influx of NEFA is increased (Drackley et al., 2001).

Although the current model represented glucose and lipid metabolism under normal conditions, the KB profile after therapeutic glucose infusion was successfully simulated in a ketotic cow. Clinical ketosis occurs when there is a failure of the homeostatic mechanisms regulating the glucose and fat metabolism. The therapeutic approach is to reestablish normal homeostasis (Herdt and Emery, 1992). The agreement between model prediction and KB profile after therapeutic treatment further supports the proposed interrelationship between glucose and lipid metabolism simulated in the model. However, only one cow was diagnosed with ketosis as presented in Figure 3, and more animals are needed to evaluate the applicability of the model under ketotic conditions in future studies.

\section{CONCLUSIONS}

Using DMI, feed composition, calf birth weight, milk yield, and milk components as driving variables, the model can explain most of the variations in body fat content, and plasma concentrations of glucose, glycerol, NEFA, and KB during the periparturient period. When using this model to quantify metabolite flows, glucose deficiency was closely related to the rate of fat mobilization. The excessive KB could result from elevated fat mobilization due to low plasma and tissue glucose concentrations. The model should be evaluated with data from independent experiments and compared with other models. In addition, more animal experiments are needed to investigate the possibility that fat is mobilized because of low glucose concentrations in periparturient cows. The model may be useful for understanding and explaining ketosis development.

\section{REFERENCES}

Baldwin, R. L. 1995. Modeling Ruminant Digestion and Metabolism. 1st ed. Chapman \& Hall, London, UK.

Bannink, A., J. Kogut, J. Kijkstra, J. France, S. Tamminga, and A. M. van Vuuren. 2000. Modelling production and portal appearance of volatile fatty acids in dairy cows. CAB International, Wallingford, UK.

Bauman, D. E., and J. M. Elliot. 1983. Control of nutrient partitioning in lactating ruminants. Elsevier, Amsterdam, the Netherlands.

Bell, A. W. 1995. Regulation of organic nutrient metabolism during transition from late pregnancy to early lactation. J. Anim. Sci. 73:2804-2819.

Bibby, J., and H. Toutenburg. 1977. Prediction and Improved Estimation in Linear Models. Wiley, London, UK.

Cadorniga-Valino, C., R. R. Grummer, L. E. Armentano, S. S. Donkin, and S. J. Bertics. 1997. Effects of fatty acids and hormones on fatty acid metabolism and gluconeogenesis in bovine hepatocytes. J. Dairy Sci. 80:646-656.
Cant, J. P., E. J. DePeters, and R. L. Baldwin. 1993. Mammary amino acid utilization in dairy cows fed fat and its relationship to milk protein depression. J. Dairy Sci. 76:762-774.

Coe, M. L., T. G. Nagaraja, Y. D. Sun, N. Wallace, E. G. Towne, K. E. Kemp, and J. P. Hutcheson. 1999. Effect of virginiamycin on ruminal fermentation in cattle during adaptation to a high concentrate diet and during an induced acidosis. J. Anim. Sci. 77:2259-2268.

Dijkstra, J., H. D. Neal, D. E. Beever, and J. France. 1992. Simulation of nutrient digestion, absorption and outflow in the rumen: Model description. J. Nutr. 122:2239-2256.

Drackley, J. K., T. R. Overton, and G. N. Douglas. 2001. Adaptations of glucose and long-chain fatty acid metabolism in liver of dairy cows during the periparturient period. J. Dairy Sci. 84(E Suppl.):100-112.

Dukes, H. H. 1993. Physiology of Domestic Animals. Comstock Publishing Associates, Ithaca, NY.

Duncan, W. R. H., and G. A. Garton. 1978. Differences in the proportions of branched-chain fatty acids in subcutaneous triacylglycerols of barley-fed ruminants. Br. J. Nutr. 40:29-33.

Elias-Calles, J. A., C. T. Gaskins, J. R. Busboom, J. D. Cronrath, S. K. Duckett, J. J. Reeves, R. W. Wright, K. A. Johnson, and C. J. Moreshead. 1997. Comparison of fatty acid composition and palatability characteristics of beef from various Wagyu sires. WSU Wagyu Proc. 3:63-86.

France, J., and J. H. Thornley. 1984. Growth functions. Pages 75-94 in Mathematical Models in Agriculture: A quantitative approach to problems in agriculture and related sciences. Butterworths, London, UK.

Greenfield, R. B., M. J. Cecava, T. R. Johnson, and S. S. Donkin. 2000. Impact of dietary protein amount and rumen undegradability on intake, peripartum liver triglyceride, plasma metabolites, and milk production in transition dairy cattle. J. Dairy Sci. 83:703710.

Guo, J., R. R. Peters, and R. A. Kohn. 2007. Effect of transition diet on production performance and metabolism in periparturient dairy cows. J. Dairy Sci. 90:5247-5258.

Harmon, D. L. 1992. Dietary influences on carbohydrases and small intestinal starch hydrolysis capacity in ruminants. J. Nutr. 122:203-210.

Hay, W. W. Jr., S. A. Myers, J. W. Sparks, R. B. Wilkening, G. Meschia, and F. C. Battaglia. 1983. Glucose and lactate oxidation rates in the fetal lamb. Proc. Soc. Exp. Biol. Med. 173:553-563.

Heitmann, R. N., D. J. Dawes, and S. C. Sensenig. 1987. Hepatic ketogenesis and peripheral ketone body utilization in the ruminant. J. Nutr. 117:1174-1180.

Herdt, T. H., and R. S. Emery. 1992. Therapy of diseases of ruminant intermediary metabolism. Vet. Clin. North Am. Food Anim. Pract. 8:91-106.

Holcomb, C. S., H. H. Van Horn, H. H. Head, M. B. Hall, and C. J. Wilcox. 2001. Effects of prepartum dry matter intake and forage percentage on postpartum performance of lactating dairy cows. J. Dairy Sci. 84:2051-2058.

House, W. A., and A. W. Bell. 1993. Mineral accretion in the fetus and adnexa during late gestation in Holstein cows. J. Dairy Sci. 76:2999-3010.

Huntington, G. B., J. H. Eisemann, and J. M. Whitt. 1990. Portal blood flow in beef steers: Comparison of techniques and relation to hepatic blood flow, cardiac output and oxygen uptake. J. Anim. Sci. 68:1666-1673.

Ingvartsen, K. L., and J. B. Andersen. 2000. Integration of metabolism and intake regulation: A review focusing on periparturient animals. J. Dairy Sci. 83:1573-1597.

Kleinbaum, D. G., L. L. Kupper, K. E. Muller, and Z. Nizam. 1998. Regression diagnostics. Page 228-233 in Applied Regression Analysis and Multivariable Methods. 3rd ed. Brooks/Cole Publishing Company, Pacific Grove, CA.

Kohn, R. A., K. F. Kalscheur, and E. Russek-Cohen. 2002. Evaluation of models to estimate urinary nitrogen and expected milk urea nitrogen. J. Dairy Sci. 85:227-233. 
Komaragiri, M. V., D. P. Casper, and R. A. Erdman. 1998. Factors affecting body tissue mobilization in early lactation dairy cows. 2. Effect of dietary fat on mobilization of body fat and protein. J. Dairy Sci. 81:169-175.

Krebs, H. A. 1966. Bovine ketosis. Vet. Rec. 78:187-192.

Kristensen, N. B., and D. L. Harmon. 2004. Splanchnic metabolism of volatile fatty acids absorbed from the washed reticulorumen of steers. J. Anim. Sci. 82:2033-2042.

Mackle, T. R., D. A. Dwyer, K. L. Ingvartsen, P. Y. Chouinard, D. A. Ross, and D. E. Bauman. 2000. Evaluation of whole blood and plasma in the interorgan supply of free amino acids for the mammary gland of lactating dairy cows. J. Dairy Sci. 83:13001309.

McNamara, J. P., and R. L. Baldwin. 2000. Estimation of parameters describing lipid metabolism in lactation: Challenge of existing knowledge described in a model of metabolism. J. Dairy Sci. 83:128-143.

Murphy, M. R., R. L. Baldwin, and L. J. Koong. 1982. Estimation of stoichiometric parameters for rumen fermentation of roughage and concentrate diets. J. Anim. Sci. 55:411-421.

National Research Council. 2001. Nutrient Requirements of Dairy Cattle. 7th rev. ed. National Academy Press, Washington, DC.

Neal, H., and J. H. Thornley. 1983. The lactation curve in cattle: A mathematical model of the mammary gland. J. Agric. Sci. Camb. 101:389-400.

Nelson, D. L., M. M. Cox, and A. L. Lehninger. 2000. Lehninger Principles of Biochemistry. 3rd ed. Worth Publishers, New York, NY.

Orskov, E. R. 1986. Starch digestion and utilization in ruminants. J. Anim. Sci. 63:1624-1633.
Parker, D. S. 1990. Manipulation of the functional activity of the gut by dietary and other means (antibiotics/probiotics) in ruminants. J. Nutr. 120:639-648.

Pethick, D. W., D. B. Lindsay, P. J. Barker, and A. J. Northrop. 1983. The metabolism of circulating non-esterified fatty acids by the whole animal, hind-limb muscle and uterus of pregnant ewes. Br. J. Nutr. 49:129-143.

Petterson, J. A., F. R. Dunshea, R. A. Ehrhardt, and A. W. Bell. 1993. Pregnancy and undernutrition alter glucose metabolic responses to insulin in sheep. J. Nutr. 123:1286-1295.

Price, T. D., and D. Rittenberg. 1950. The metabolism of acetone. I. Gross aspects of catabolism and excretion. J. Biol. Chem. 185:449-459.

Reynolds, C. K., P. C. Aikman, B. Lupoli, D. J. Humphries, and D. E. Beever. 2003. Splanchnic metabolism of dairy cows during the transition from late gestation through early lactation. J. Dairy Sci. 86:1201-1217.

Reynolds, C. K., G. B. Huntington, H. F. Tyrrell, and P. J. Reynolds. 1988. Net metabolism of volatile fatty acids, D-betahydroxybutyrate, nonesterified fatty acids, and blood gasses by portal-drained viscera and liver of lactating Holstein cows. J. Dairy Sci. 71:2395-2405.

Scientist Handbook. 1995. Experimental data fitting; Microsoft windows version. SofMicroMath Inc., Salt Lake City, UT.

Sunehag, A. L., K. Louie, J. L. Bier, S. Tigas, and M. W. Haymond. 2002. Hexoneogenesis in the human breast during lactation. J. Clin. Endocrinol. Metab. 87:297-301. 